\title{
Heading of shoots and hand thinning of flowers and fruits on 'BRS Kampai' peach trees
}

\author{
Paula Duarte de Oliveira(1), Gilmar Arduino Bettio Marodin ${ }^{(1)}$, Gustavo Klamer de Almeida(1), \\ Mateus Pereira Gonzatto ${ }^{(1)}$ and Daniel Chamorro Darde ${ }^{(1)}$
}

(1)Universidade Federal do Rio Grande do Sul, Avenida Bento Gonçalves, no 7.712, Agronomia, CEP 91540-000 Porto Alegre, RS, Brazil. E-mail: poulduarte@hotmail.com, marodin@ufrgs.br, gklalmeida@hotmail.com, mpgonzatto@gmail.com, danieldarde@gmail.com

\begin{abstract}
The objective of this work was to evaluate the effect of shoot heading and of hand thinning in different development stages of flowers and fruits on the fruit production and quality of 'BRS Kampai' peach (Prunus persica) trees. The experiment was performed during three crop years, under the conditions of the "Depressão Central" region in the state of Rio Grande do Sul, Brazil, and the treatments were: T1, heading of half of the mixed shoot; T2, heading of one third of the mixed shoot; T3, flower thinning in the pink bud stage; T4, thinning at full bloom; T5, thinning of fruit with $5 \mathrm{~mm}$; T6, thinning of fruit with $20 \mathrm{~mm}$; and T7, no thinning or heading (control). Fruit production and quality were evaluated. Plants with no thinning were more productive, but showed high frequency of fruits with a diameter smaller than $60 \mathrm{~mm}$. Shoot heading reduced production per tree and resulted in small-sized fruit. Thinning time did not affect production, and fruit size was greater when thinning was performed at the bloom stage. 'BRS Kampai' peach trees can be thinned starting at bloom, which provides greater fruit size, with no production loss.
\end{abstract}

Index terms: Prunus persica, fruit quality, yield.

\section{Desponte de ramos e raleio manual de flores e frutos em pessegueiros 'BRS Kampai'}

\begin{abstract}
Resumo - O objetivo deste trabalho foi avaliar o efeito do desponte de ramos e do raleio manual realizado em diferentes estágios de desenvolvimento de flores e frutos sobre a produção e a qualidade dos frutos do pessegueiro (Prunus persica) 'BRS Kampai'. O experimento foi realizado durante três safras nas condições da Depressão Central do Rio Grande do Sul, e os tratamentos foram: T1, desponte da metade do ramo misto; T2, desponte de um terço do ramo misto; T3, raleio de flor no estádio de balão rosado; T4, raleio na plena floração; T5, raleio do fruto com $5 \mathrm{~mm}$; T6, raleio do fruto com $20 \mathrm{~mm}$; e T7, sem desponte ou raleio (testemunha). Avaliaram-se a produção e a qualidade dos frutos. Plantas sem raleio foram mais produtivas, mas com alta frequência de frutos com diâmetro inferior a $60 \mathrm{~mm}$. O desponte reduziu a produção por planta e ocasionou frutos pequenos. A época de raleio não afetou a produção, e o diâmetro dos frutos foi maior quando o raleio foi realizado durante a floração. Pessegueiros 'BRS Kampai' podem ser raleados a partir da floração, o que proporciona maior tamanho dos frutos, sem reduzir a produção.
\end{abstract}

Termos para indexação: Prunus persica, qualidade de fruto, produtividade.

\section{Introduction}

In Brazil, the state of Rio Grande do Sul is the largest producer of peaches [Prunus persica (L.) Batsch], with 13,000 hectares of harvested area and about 128,000 tons of fruits destined for the canning industry and the fresh market (Produção..., 2014).

For the fresh market, peach fruit quality is extremely important for a successful commercialization, because size, color, and absence of defects are the main criteria used by consumers while buying fruits (Trevisan et al., 2010). Small fruit size stands out as the characteristic that causes the greatest reductions in the selling prices of peaches -35 and $39 \%$ in the wholesale and retail markets, respectively (Lima et al., 2009).

The peach tree, under favorable conditions, shows a fruit set larger than necessary to assure an adequate commercial production. For this reason, the thinning of fruits and flowers is a cultural practice often adopted in all production regions, aiming to increase fruit size and quality, enhancing its value at harvest (Osborne \& Robinson, 2008; Turk et al., 2014).

In peaches, thinning is mostly done by hand, through the removal of fruit with $20 \mathrm{~mm}$ of diameter, about 40 
to 50 days after full bloom (DAFB). However, thinning has a greater impact on fruit size when it is performed before or during the full bloom stage, rather than at 40 to $50 \mathrm{DAFB}$, due to a better nutritional balance among sink tissues from the beginning of the growth stage onwards, increasing the frequency of fruits larger than $60 \mathrm{~mm}$ in diameter (Myers et al., 2002; Byers et al., 2003; Szot, 2010).

Thinning is a delicate operation that demands high labor. A common alternative practice among the peach farmers in the state of Rio Grande do Sul is shortening bearing shoots, not thinning them, in order to reduce the number of fruits per plant. Although early thinning and shoot heading seem beneficial, there are no known researches comparing their effects from the bloom period to fruit thinning time, in the conditions of Southern Brazil.

The objective of this work was to evaluate the effect of shoot heading and of hand thinning in different development stages of flowers and fruits on the fruit production and quality of 'BRS Kampai' peach trees.

\section{Materials and Methods}

The experiment was conducted in the 2013, 2014, and 2015 crop years in an experimental orchard of the agricultural experimental station of Universidade Federal do Rio Grande do Sul, located in the "Depressão Central" region of the municipality of Eldorado do Sul, in the state of Rio Grande do Sul, Brazil (3006'33"S, 5140'14"W). The soil prevailing in the region is an Argissolo Vermelho distrófico típico (Sistema..., 1999), i.e., a Rhodic Ultisol. The climate is the fundamental type Cfa, according to Köppen's classification, that is, mild temperate fully humid with hot summer. On the coldest months (June, July, and August), the average temperature is $8.9^{\circ} \mathrm{C}$, and, on the hottest ones (January and February), the average temperature is around $29-30^{\circ} \mathrm{C}$. The annual average rainfall is $1,445 \mathrm{~mm}$ (Bergamaschi et al., 2013). The weather conditions during the experimental period are shown in Figure 1.

The peach cultivar used was BRS Kampai, which is destined for the fresh market and is characterized by early ripening (first fortnight of November in the state of Rio Grande do Sul), white flesh, sweet taste, and low acidity (Raseira et al., 2010). At the beginning of the treatments, in 2013, the plants were three years old.
The rootstock used was 'Capdeboscq', and the plants were spaced at $2.5 \times 5.5 \mathrm{~m}$, trained to a vase with four scaffold branches. The assessed treatments were: T1, heading of half of the mixed shoot; T2, heading of one third of the mixed shoot; T3, flower thinning in the pink bud stage; T4, thinning at full bloom $(70 \%$ of open flowers); T5, thinning of fruit with $5 \mathrm{~mm}$; T6, thinning of fruit with $20 \mathrm{~mm}$; and $\mathrm{T} 7$, no thinning or heading (control). Thinning was performed selectively: on medium-sized shoots, four to five flowers or fruits spaced at 8 to $10 \mathrm{~cm}$ were left; and on thinner shoots, one to two flowers or fruits spaced at 12 to $15 \mathrm{~cm}$ were left. No fruits were left on mixed shoots, which had no leaves. The treatments were repeated on the same plants in the three evaluated years.

The experimental design was a completely randomized block with six replicates, with one useful plant per experimental unit. Cultural practices, such as fertilization, winter and summer pruning, chemical treatments, and weed control, were performed evenly in the entire orchard, according to the standards for the integrated production of peach (Fachinello et al., 2005).

Fruit growth was evaluated in 2014 and 2015. For that, four shoots per plant were marked at the mid-section of each major branch, where the suture diameter of a total of eight fruits was measured using a digital caliper. There was an interval of about ten days between measurements.

In the three study years, fruit yield was obtained by weighing all fruits $(\mathrm{kg})$ per plant at harvest, and average fruit weight was obtained by dividing production by the number of the fruits harvested per plant. After harvest, all picked fruits were ranked into four diameter classes: higher than $70 \mathrm{~mm}$, very large fruits; between $60-70 \mathrm{~mm}$, large fruits; between $50-$ $60 \mathrm{~mm}$, average fruits; and lower than $50 \mathrm{~mm}$, small fruits (Raseira et al., 2014).

Ten fruits per experimental unit were sampled for the physicochemical analysis. The background color of fruit epidermis was measured using the CR-400 colorimeter (Konica Minolta Sensing Americas, Inc., Ramsey, NJ, USA), calibrated on a white porcelain surface. Readings were taken on the fruit equatorial region, by setting the values of luminosity ( $\left.\mathrm{L}^{*}\right)$, chroma in the red-green axis $\left(\mathrm{a}^{*}\right)$, and chroma in the yellow-blue axis $\left(b^{*}\right)$, and calculating the hue angle $\left(h^{\circ}\right)$ and chroma angle $\left(C^{*}\right)$. The $L^{*}$ value ranges between 0 (absolute black) and 100 (absolute white);

Pesq. agropec. bras., Brasília, v.52, n.11, p.1006-1016, nov. 2017 DOI: 10.1590/S0100-204X2017001100006 
$\mathrm{h}^{\circ}$ sets the color tone, in which angle $0^{\circ}$ stands for red color, $90^{\circ}$ for yellow, $180^{\circ}$ for green, and $270^{\circ}$ for blue; and $\mathrm{C}^{*}$ indicates color saturation or intensity, in which 0 represents little saturation (Konica Minolta, 2007). Flesh firmness was measured with an $8-\mathrm{mm}$ tip bench penetrometer, at the equatorial cheeks of the fruit; the soluble solids content (SSC) was measured using a digital refractometer; and titratable acidity was obtained by titration with $0.1 \mathrm{~mol} \mathrm{~L}^{-1}$ sodium hydroxide, expressed as grams of malic acid $100 \mathrm{~g}^{-1}$ pulp. Data were analyzed as repeated measures using the Proc Mixed procedure of the SAS software, version 9.4 (SAS Institute Inc., Cary, NC, USA). Covariance structures were tested, and the one with a better adjustment to each variable was selected, according to the Akaike and Bayesian information criterion (Silva et al., 2015). The treatment $\times$ year interaction was considered significant by the F-test, at $25 \%$ probability (Perecin \& Cargnelutti Filho, 2008). When the F-test was significant, orthogonal contrasts were used as a complementation of the analysis of variance. The built orthogonal contrasts were: $\mathrm{C} 1$, control vs. heading and thinning (T7 vs. T1, T2, T3, T4, T5, and T6); C2, heading vs. thinning ( $\mathrm{T} 1$ and $\mathrm{T} 2$ vs. T3, T4, T5, and T6); $\mathrm{C} 3$, heading of half of the mixed shoot vs. heading of one third of the mixed shoot (T1 vs. T2); C4, thinning of fruit with $20 \mathrm{~mm}$ vs. thinning of fruit with $5 \mathrm{~mm}$ and

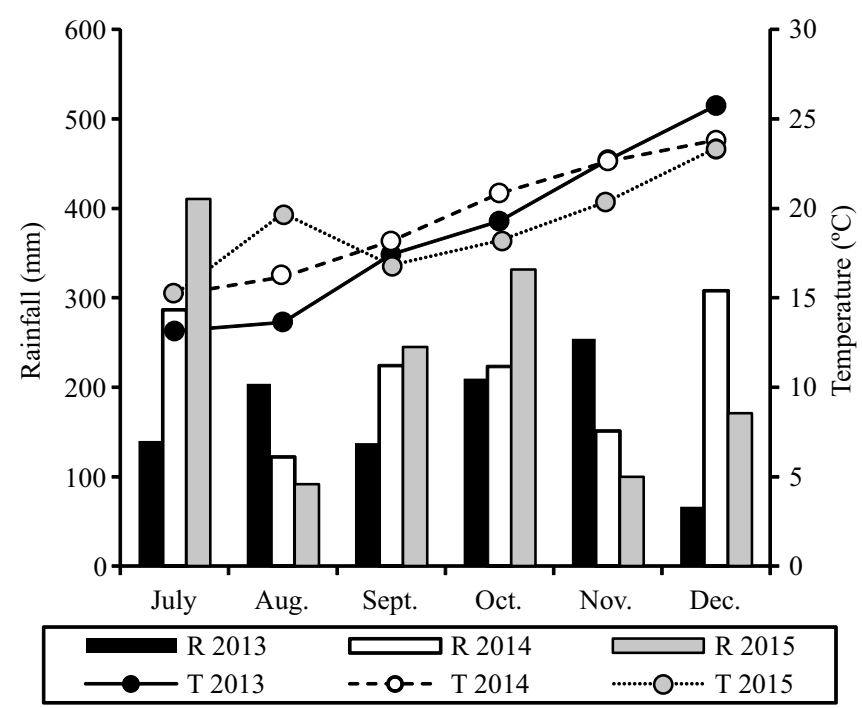

Figure 1. Rainfall $(\mathrm{R})$ and average air temperature $(\mathrm{T})$ during the experimental period, from 2013 to 2015, in the municipality of Eldorado do Sul, in the state of Rio Grande do Sul, Brazil. flower thinning (T6 vs. T3, T4, and T5); C5, thinning of fruit with $5 \mathrm{~mm}$ vs. flower thinning (T5 vs. T3 and T4); and C6, flower thinning at the pink bud stage vs. thinning at full bloom (T3 vs. T4). The contrasts were significant by the F-test, at 5\% probability.

\section{Results and Discussion}

The thinning and heading treatments affected the fruit growth of the 'BRS Kampai' peach tree (Figure 2). In 2014, the fruit growth behavior was as expected for peach fruits, according to Silva et al. (2013). In this year, non-thinned plants showed lower fruit growth than those that had been thinned or headed, especially in the last assessment, which corresponds to stage III of growth. The heading of half of the shoot and of one third of the shoot led to a lower fruit growth, compared with the thinning treatments, which did not differ among themselves. No differences were detected between flower and fruit thinning times. In 2015, fruit diameter evaluations were performed late, during the stage III of growth (Figure 3). In this year, no difference was observed between the control and the average of treatments. Heading treatments again caused a smaller fruit diameter than the thinning ones, considering the average of the study period. Regarding thinning times, plants thinned at the pink bud stage induced lower fruit growth than those at full bloom.

In 2015, no differences regarding fruit growth were found between the control plants and those thinned or headed, which is possibly due to the similar yield between treatments (Table 1). However, in the two evaluated years, heading treatments showed higher yield than the thinning ones, which led to a lower fruit growth. This result may be attributed to the fact that the heading treatments reduce the number of flower and vegetative buds on the plant, consequently reducing the number of leaves. The decrease in the amount of sink tissue should have increased fruit size, but it is possible that the number of leaves was not enough to sustain the fruit demand for carbohydrates. According to Gugliuzza et al. (2002), the fruit position in relation to the leaves can also interfere with its growth, as the proximity between source and sink tissues allows maximum fruit growth. Therefore, thinning of flowers or fruits may provide an even distribution of fruits along the shoots, allowing better fruit growth than shoot heading. 
Yield per plant showed main effect for treatment and year, indicating that the differences between treatments occurred in the average of the year and between years in the average of the treatments (Table 1). The average yield of the three experimental years was higher in non-thinned plants (22.87 kg per plant), compared with those that were subjected to thinning or heading of shoots (16.27 kg per plant). It should be noted that the other treatments showed no significant differences.

Similar results were found in other peach thinning researches, in which thinned plants showed lower yield due to the reduced number of fruits per plant (Scarpare Filho et al., 2000; El-Boray et al., 2013). According to Osborne \& Robinson (2008), thinning reduces plant
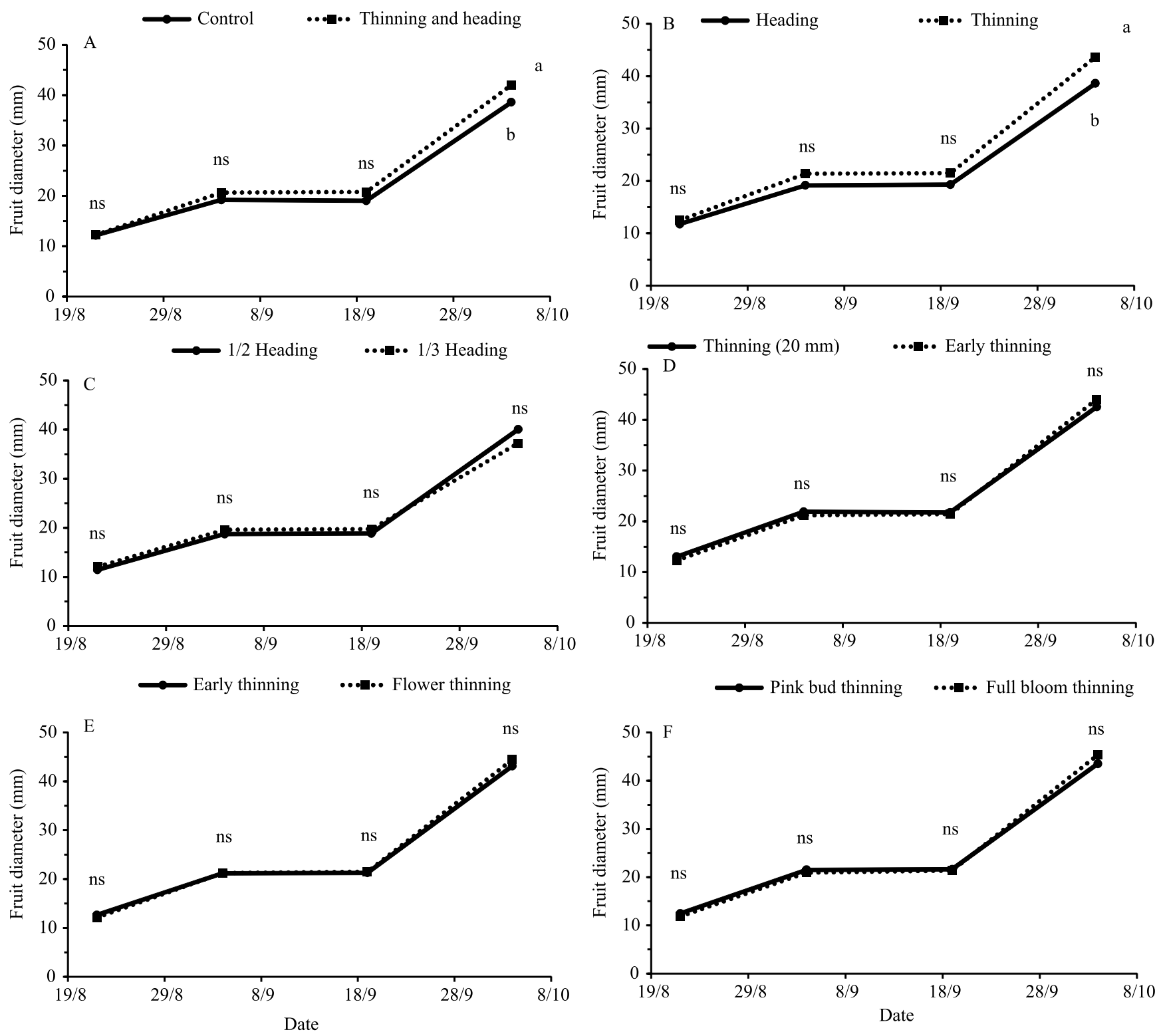

Figure 2. Fruit growth curve of 'BRS Kampai' peach (Prunus persica) tree subjected to heading of shoots and hand thinning of flowers and fruits in 2014, in the municipality of Eldorado do Sul, in the state of Rio Grande do Sul, Brazil: A, control vs. heading and thinning (T7 vs. T1, T2, T3, T4, T5, and T6); B, heading vs. thinning (T1 and T2 vs. T3, T4, T5, and T6); C, heading of half of the mixed shoot vs. heading of one third of the mixed shoot (T1 vs. T2); D, thinning of fruit with $20 \mathrm{~mm}$ vs. thinning of fruit with $5 \mathrm{~mm}$ and flower thinning (T6 vs. T3, T4, and T5); E, thinning of fruit with $5 \mathrm{~mm}$ vs. flower thinning (T5 vs. T3 and T4); and F, flower thinning at the pink bud stage vs. thinning at full bloom (T3 vs. T4). ${ }^{\text {ns Nonsignificant. }}$ 
yield; however, it also promotes a significant increase in the average fruit size, improving commercial value, which compensates yield losses.

Fruit average weight showed significant treatment $x$ year interaction, since fruit development was observed each year. In 2013 and 2014, non-thinned plants produced fruits with lower average weight than those of the other treatments (Table 1). Besides, plants with headed shoots produced smaller fruits than those subjected to flower or fruit thinning during the evaluated years. In 2014, plants at the pink bud, full bloom, and 5-mm fruit stages, in the average of
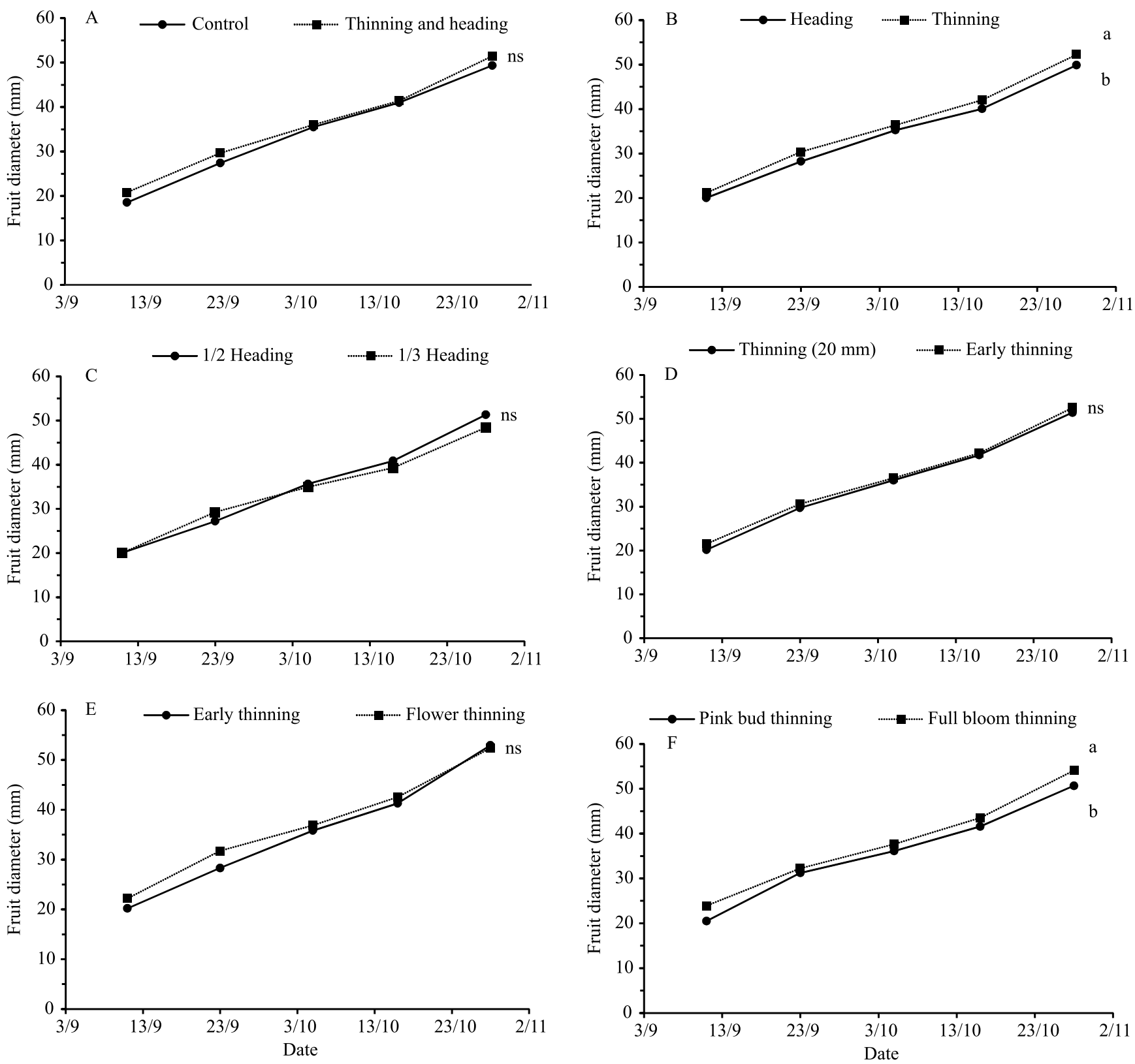

Figure 3. Fruit growth curve of 'BRS Kampai' peach (Prunus persica) tree subjected to heading of shoots and hand thinning of flowers and fruits in 2015, in the municipality of Eldorado do Sul, in the state of Rio Grande do Sul, Brazil: A, control vs. heading and thinning (T7 vs. T1, T2, T3, T4, T5, and T6); B, heading vs. thinning (T1 and T2 vs. T3, T4, T5, and T6); C, heading of half of the mixed shoot vs. heading of one third of the mixed shoot (T1 vs. T2); D, thinning of fruit with 20 mm vs. thinning of fruit with $5 \mathrm{~mm}$ and flower thinning (T6 vs. T3, T4, and T5); E, thinning of fruit with $5 \mathrm{~mm}$ vs. flower thinning

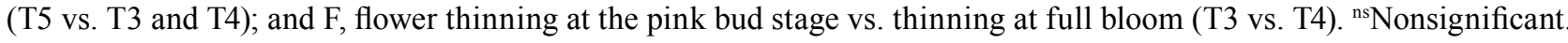


treatments, showed higher fruit weight than those thinned at the 20-mm fruit stage.

Performing early thinning on the flowering stages may increase the final fruit size, which can be explained by a reduction in the initial carbohydrate competition (El-Boray et al., 2013). An increment of fruit average weight due to early thinning was also observed by Szot (2010) in apple (Malus domestica Borkh.) trees and by Cittadini et al. (2013) in cherry Prunus avium (L.) trees. In the present study, although the thinning treatments increased the average weight of fruits, it was not enough to match the yield of the control treatment. However, the high production verified in the control treatment may not result in greater profitability, because most fruits had no commercial value (Figure 3). Therefore, shoot heading reduced fruit production per plant and only slightly increased fruit size. This shows that this practice should be complemented by the hand thinning of fruits to adjust the fruit load.

Fruit distribution by diameter class differed greatly between treatments (Figure 4). Non-thinned plants showed a low frequency of fruits in the 60 to $70-\mathrm{mm}$ (large fruits) and in the $>70$-mm (very large fruits) classes. Summed up, these classes represented a percentage of 17, 10.1, and $17.3 \%$ in the 2013, 2014, and 2015 crop years, respectively. A total of 49.0, 11.6, and $21.3 \%$ fruits with a diameter above $60 \mathrm{~mm}$ were produced in the treatment heading of half of the shoot, and of 38.6, 28.4, and $37.4 \%$ in the heading of one third of the shoot, in the 2013, 2014, and 2015 crop years, respectively. In regular thinning, when fruits were about $20 \mathrm{~mm}$ in diameter, the distribution of fruits in the classes above $60 \mathrm{~mm}$ was 70.4, 36.2, and 43.0\%. When thinning was performed on young fruits $(5 \mathrm{~mm})$, the distribution was $81.1,50.0$, and $60.8 \%$ in the 2013 , 2014 , and 2015 crop years, respectively.

The increase in the fruit diameter of plants thinned during the flowering stage has been reported as the main benefit of this practice (Byers et al., 2003; Osborne \& Robinson, 2008). According to Szot (2010), thinning of apple trees from the pink bud to the end of the flowering stage significantly increased

Table 1. Yield per plant and fruit weight of 'BRS Kampai' peach (Prunus persica) tree subjected to heading of shoots and hand thinning of flowers and fruits, in the municipality of Eldorado do Sul, in the state of Rio Grande do Sul, Brazil.

\begin{tabular}{|c|c|c|c|c|c|c|}
\hline \multirow[t]{2}{*}{ Treatment $^{(1)}$} & \multicolumn{3}{|c|}{ Yield (kg per plant) } & \multicolumn{3}{|c|}{ Fruit weight $(\mathrm{g})$} \\
\hline & 2013 & 2014 & 2015 & 2013 & 2014 & 2015 \\
\hline T1 & 14.08 & 20.11 & 16.13 & 101.98 & 93.31 & 106.54 \\
\hline $\mathrm{T} 2$ & 18.23 & 20.75 & 18.84 & 111.44 & 77.86 & 107.59 \\
\hline $\mathrm{T} 3$ & 11.91 & 18.35 & 11.33 & 124.52 & 108.62 & 120.44 \\
\hline $\mathrm{T} 4$ & 13.02 & 21.84 & 14.5 & 135.6 & 114.69 & 128.77 \\
\hline T5 & 13.25 & 17.66 & 12.59 & 127.89 & 114.19 & 117.38 \\
\hline T6 & 13.49 & 17.27 & 19.59 & 125.75 & 77.65 & 114.11 \\
\hline $\mathrm{T} 7$ & 25.52 & 23.7 & 19.41 & 80.46 & 74.41 & 111.63 \\
\hline \multirow[t]{2}{*}{ Coefficient of variation (\%) } & & 34.50 & & & 15.76 & \\
\hline & \multicolumn{6}{|c|}{ Probability value for the F-test } \\
\hline Treatment $^{(2)}$ & & 0.0086 & & & $<0.0001$ & \\
\hline Year & & 0.0009 & & & $<0.0001$ & \\
\hline Treatment vs. year ${ }^{(3)}$ & & 0.2894 & & & 0.0083 & \\
\hline Contrast $^{(4)}$ & \multicolumn{6}{|c|}{ Probability value } \\
\hline $\mathrm{C} 1$ & & 0.0007 & & $<0.0001$ & 0.0028 & 0.5833 \\
\hline $\mathrm{C} 2$ & & 0.0716 & & 0.0006 & 0.0036 & 0.0339 \\
\hline $\mathrm{C} 3$ & & 0.2855 & & 0.344 & 0.1236 & 0.9158 \\
\hline $\mathrm{C} 4$ & & 0.3341 & & 0.6597 & $<0.0001$ & 0.3214 \\
\hline $\mathrm{C} 5$ & & 0.7422 & & 0.8013 & 0.7694 & 0.4035 \\
\hline $\mathrm{C} 6$ & & 0.2685 & & 0.2680 & 0.5427 & 0.4047 \\
\hline
\end{tabular}

(1) T1, heading of half of the mixed shoot; T2, heading of one third of the mixed shoot; T3, flower thinning in the pink bud stage; T4, thinning at full bloom; $\mathrm{T} 5$, thinning of fruit with $5 \mathrm{~mm}$; T6, thinning of fruit with $20 \mathrm{~mm}$; and T7, no thinning or heading (control). ${ }^{(2)} \mathrm{F}$-test significant at $5 \%$ probability. ${ }^{\left({ }^{3}\right)} \mathrm{F}$-test significant at $25 \%$ probability. ${ }^{(4)} \mathrm{C} 1$, control vs. heading and thinning (T7 vs. T1, T2, T3, T4, T5, and T6); C2, heading vs. thinning (T1 and T2 vs. T3, T4, $\mathrm{T} 5$, and T6); $\mathrm{C} 3$, heading of half of the mixed shoot vs. heading of one third of the mixed shoot (T1 vs. T2); C4, thinning of fruit with 20 mm vs. thinning of fruit with $5 \mathrm{~mm}$ and flower thinning (T6 vs. T3, T4, and T5); C5, thinning of fruit with $5 \mathrm{~mm}$ vs. flower thinning (T5 vs. T3 and T4); and C6, flower thinning at the pink bud stage vs. thinning at full bloom (T3 vs. T4); contrasts are significant at $5 \%$ probability. 

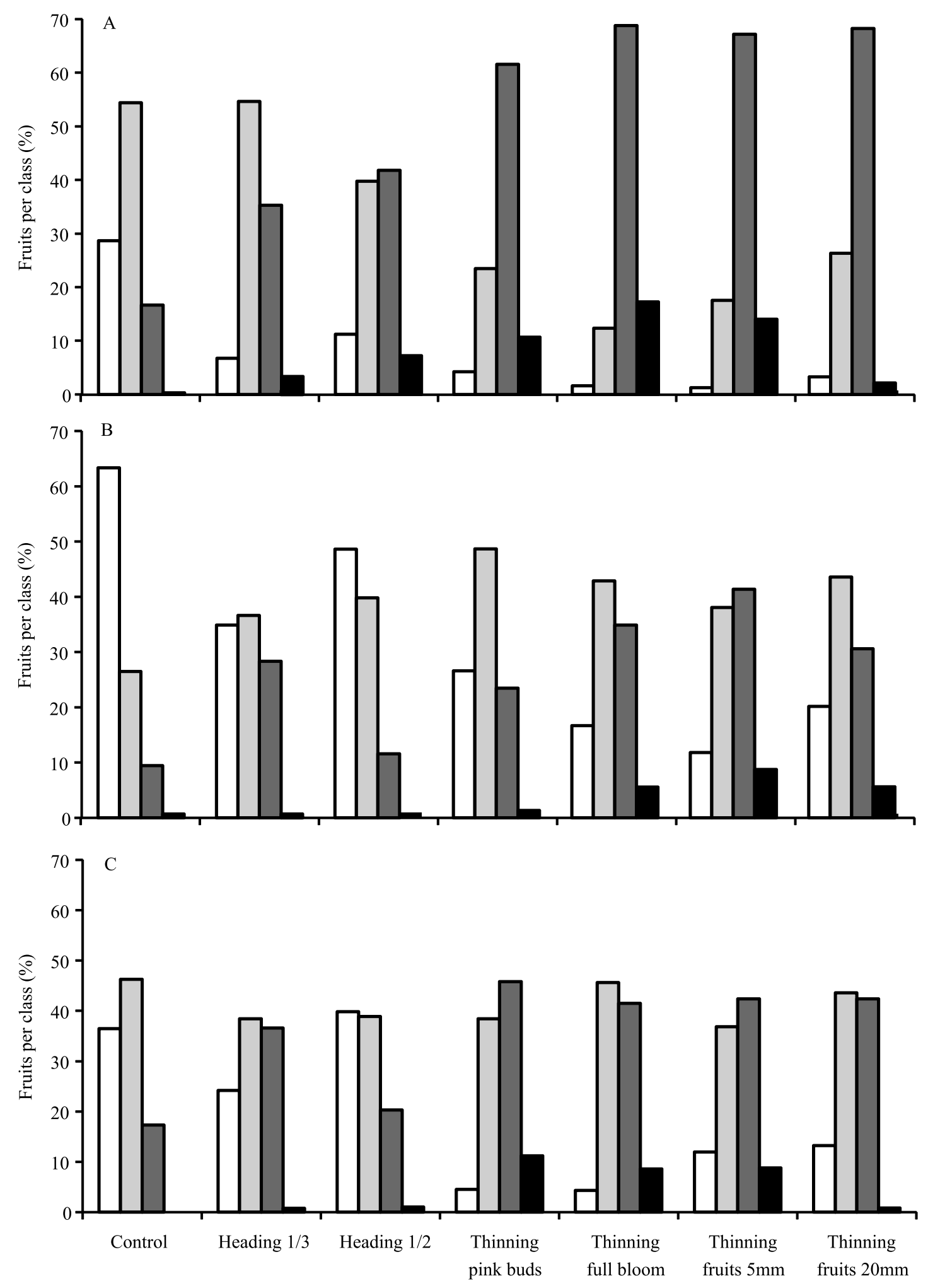

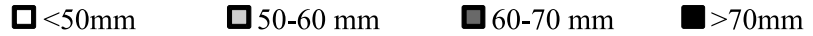

Figure 4. Fruits of 'BRS Kampai' peach (Prunus persica) tree subjected to heading of shoots and hand thinning of flowers and fruits, distributed in the following diameter classes: $>70 \mathrm{~mm}, 60$ to $70 \mathrm{~mm}, 50$ to $60 \mathrm{~mm}$, and $<50 \mathrm{~mm}$, in the 2013 (A), 2014 (B), and 2015 (C) crop years in the municipality of Eldorado do Sul, in the state of Rio Grande do Sul, Brazil. 
the frequency of fruits with a diameter above $70 \mathrm{~mm}$, which was related to the larger number of cortex cells in the fruits. In peach trees, thinning at full bloom by removing $50 \%$ of the flowers, followed by load adjustment at 42 DAFB, increased the percentage of fruit with a large diameter $(\geq 62 \mathrm{~mm})$, compared with the same thinning level performed only at 42 DAFB (Myers et al., 2002). According to these authors, partial flower thinning promotes flexibility to manage certain risks, such as the variability of the fruit set and the occurrence of late frosts.

Regarding the other physicochemical characteristics, it was observed that flesh firmness was not affected by the treatments (Table 2). SSC differed significantly in the 2013 and 2015 crop years. In 2013, fruits from the control treatment showed lower SCC $\left(9.75^{\circ}\right.$ Brix) than those of the other treatments (10.64 $\left.{ }^{\circ} \mathrm{Brix}\right)$. Fruits from thinned plants showed higher SCC than those from plants headed in 2013 and 2015. In 2015, the highest SCC was verified in fruits from plants thinned at the flowering stage (11.42 ${ }^{\circ}$ Brix). Titratable acidity, in 2015, was higher in the heading treatments than in the thinning ones; however, among thinning treatments, it was lower when fruits with a 5-mm diameter were

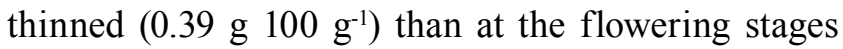

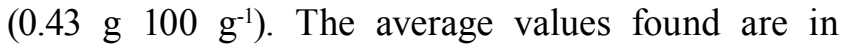
alignment with those obtained for the BRS Kampai cultivar by Raseira et al. (2010) and Gonçalves et al. (2014).

The differences in the physicochemical characteristics observed between seasons are due to variations in the meteorological conditions or to the different ripening stages at harvest. There was an increase in titratable acidity and a decrease in SCC in

Table 2. Flesh firmness, soluble solids content, and titratable acidity (TA) of fruits of 'BRS Kampai' peach (Prunus persica) tree subjected to heading of shoots and hand thinning of flowers and fruits, in the municipality of Eldorado do Sul, in the state of Rio Grande do Sul, Brazil.

\begin{tabular}{|c|c|c|c|c|c|c|c|c|}
\hline \multirow[t]{2}{*}{ Treatment $^{(1)}$} & \multicolumn{3}{|c|}{ Firmness $(\mathrm{N})$} & \multicolumn{3}{|c|}{ Soluble solids content ( ${ }^{\circ}$ Brix $)$} & \multicolumn{2}{|c|}{ TA (g $100 \mathrm{~g}^{-1}$ pulp) } \\
\hline & 2013 & 2014 & 2015 & 2013 & 2014 & 2015 & 2014 & 2015 \\
\hline $\mathrm{T} 1$ & 47.6 & 51 & 52.6 & 10.6 & 9.88 & 9.37 & 0.398 & 0.457 \\
\hline $\mathrm{T} 2$ & 50.1 & 51.2 & 54.8 & 9.81 & 10.31 & 9.59 & 0.417 & 0.466 \\
\hline $\mathrm{T} 3$ & 55.8 & 51.2 & 57.6 & 11.02 & 10.18 & 11.75 & 0.397 & 0.425 \\
\hline $\mathrm{T} 4$ & 51.9 & 56.1 & 53.2 & 10.56 & 10.01 & 11.89 & 0.392 & 0.444 \\
\hline T5 & 50.6 & 53.4 & 49.5 & 11.16 & 10.75 & 10.64 & 0.390 & 0.397 \\
\hline T6 & 50.4 & 51.4 & 54.4 & 10.7 & 10.45 & 10.23 & 0.385 & 0.442 \\
\hline $\mathrm{T} 7$ & 48.3 & 48.2 & 53.1 & 9.75 & 9.73 & 10.15 & 0.393 & 0.454 \\
\hline \multirow[t]{2}{*}{ Coefficient of variation (\%) } & \multicolumn{3}{|c|}{11.24} & \multicolumn{3}{|c|}{8.14} & \multicolumn{2}{|c|}{10.15} \\
\hline & \multicolumn{8}{|c|}{ Probability value for the F-test } \\
\hline Treatment $^{(2)}$ & \multicolumn{3}{|c|}{0.0691} & \multicolumn{3}{|c|}{$<0.0001$} & \multicolumn{2}{|c|}{0.0306} \\
\hline Year & \multicolumn{2}{|c|}{0.036} & & \multicolumn{3}{|c|}{0.1261} & \multicolumn{2}{|c|}{$<0.0001$} \\
\hline Treatment vs. year ${ }^{(3)}$ & \multicolumn{2}{|c|}{0.7356} & & \multicolumn{3}{|c|}{0.0038} & \multicolumn{2}{|c|}{0.0451} \\
\hline Contrast $^{(3)}$ & \multicolumn{8}{|c|}{ Probability value } \\
\hline $\mathrm{C} 1$ & - & - & - & 0.0191 & 0.1561 & 0.2609 & 0.8411 & 0.2957 \\
\hline $\mathrm{C} 2$ & - & - & - & 0.0301 & 0.4054 & $<0.0001$ & 0.1792 & 0.0079 \\
\hline $\mathrm{C} 3$ & - & - & - & 0.1121 & 0.3772 & 0.6584 & 0.3616 & 0.6424 \\
\hline $\mathrm{C} 4$ & - & - & - & 0.5978 & 0.7389 & 0.0040 & 0.6337 & 0.2155 \\
\hline $\mathrm{C} 5$ & - & - & - & 0.3829 & 0.1277 & 0.0112 & 0.8096 & 0.0442 \\
\hline C6 & - & - & - & 0.3504 & 0.7337 & 0.7933 & 0.8022 & 0.3575 \\
\hline
\end{tabular}

(1) T1, heading of half of the mixed shoot; T2, heading of one third of the mixed shoot; T3, flower thinning in the pink bud stage; T4, thinning at full bloom; $\mathrm{T}$, thinning of fruit with $5 \mathrm{~mm}$; T6, thinning of fruit with $20 \mathrm{~mm}$; and T7, no thinning or heading (control). ${ }^{(2)} \mathrm{F}$-test significant at $5 \%$ probability. ${ }^{(2)} \mathrm{F}$-test significant at $25 \%$ probability. ${ }^{(3)} \mathrm{C} 1$, control vs. heading and thinning (T7 vs. T1, T2, T3, T4, T5, and T6); C2, heading vs. thinning (T1 and T2 vs. T3, T4, $\mathrm{T} 5$, and T6); C3, heading of half of the mixed shoot vs. heading of one third of the mixed shoot (T1 vs. T2); C4, thinning of fruit with $20 \mathrm{~mm}$ vs. thinning of fruit with $5 \mathrm{~mm}$ and flower thinning (T6 vs. T3, T4, and T5); C5, thinning of fruit with $5 \mathrm{~mm}$ vs. flower thinning (T5 vs. T3 and T4); and C6, flower thinning at the pink bud stage vs. thinning at full bloom (T3 vs. T4); contrasts are significant at $5 \%$ probability. 
fruits of plants subjected to shoot heading, which can also be related to different ripening stages. In the same way, the higher SCC and lower titratable acidity found in fruits of thinned plants may be explained by the advanced ripening at the floral stages, in comparison with the young fruit stage $(5 \mathrm{~mm})$.

The reduction in titratable acidity during the ripening stage occurs because the organic acids are degraded, increasing the phosphoenolpyruvate levels, which activate the gluconeogenesis route and increase sugar accumulation (Etienne et al., 2013). Differences in the SCC among different thinning times can also be attributed to the sink/source proportion. The sugars of peaches, mainly sucrose, increase rapidly during the plant's development (Desnoues et al., 2014). With it, the early adjustment of the number of fruits per plant can increase final sugar accumulation due to the reduction in the number of sinks.

The color of fruit epidermis, in 2013, did not differ significantly between treatments (Table 3 ). The value of $\mathrm{h}^{\circ}$, measured on the shaded side of the fruit, varied from
91.6 to $95.7^{\circ}$, showing a yellow to slightly greenish color. In 2014, the fruit color tonality did not differ between treatments, with an average $h^{\circ}$ value of $92.6^{\circ}$. The fruits from plants thinned at the full bloom stage showed a higher $\mathrm{C}^{*}$ value and a lower $\mathrm{L}^{*}$, i.e., had a darker and more intense coloration, when compared with plants thinned at the pink bud stage. In 2015, in general, the fruits showed more reddish coloration than in the other years, with $h^{\circ}$ ranging from 66.9 to $79.8^{\circ}$. A significant difference in the $\mathrm{L}^{*}, \mathrm{C}^{*}$, and $\mathrm{h}^{\circ}$ values was observed only between thinning in the pink bud and full bloom treatments, in 2014 and 2015. However, the difference between these treatments varied among years.

According to Ferrer et al. (2005), background coloration is a good ripening and harvest time index for peach. In the present study, background coloration did not differ between treatments or the differences were nonsignificant, which shows that the external ripening of fruits was not affected by the treatments.

The obtained results are an indicative that the 'BRS Kampai' peach tree can be thinned early, starting at

Table 3. Value of luminosity $\left(\mathrm{L}^{*}\right)$, chroma $\left(\mathrm{C}^{*}\right)$, and hue $\left(\mathrm{h}^{\circ}\right)$ of fruits of 'BRS Kampai' peach (Prunus persica) tree subjected to heading of shoots and hand thinning of flowers and fruits, in the municipality of Eldorado do Sul, in the state of Rio Grande do Sul, Brazil.

\begin{tabular}{|c|c|c|c|c|c|c|c|c|c|}
\hline \multirow[t]{2}{*}{ Treatment $^{(1)}$} & \multicolumn{3}{|c|}{$\mathrm{L}^{*}$} & \multicolumn{3}{|c|}{$\mathrm{C}^{*}$} & \multicolumn{3}{|c|}{$\mathrm{h}^{\circ}$} \\
\hline & 2013 & 2014 & 2015 & 2013 & 2014 & 2015 & 2013 & 2014 & 2015 \\
\hline $\mathrm{T} 1$ & 75.0 & 72.4 & 65.9 & 9.3 & 9.1 & 8.7 & 94.6 & 97.4 & 76.3 \\
\hline $\mathrm{T} 2$ & 74.5 & 71.0 & 64.5 & 9.2 & 9.0 & 8.6 & 93.6 & 93.3 & 74.8 \\
\hline $\mathrm{T} 3$ & 74.5 & 72.2 & 64.4 & 9.2 & 9.1 & 8.7 & 95.8 & 93.2 & 67.0 \\
\hline $\mathrm{T} 4$ & 75.0 & 68.2 & 69.0 & 9.2 & 8.8 & 9.0 & 94.9 & 87.1 & 79.8 \\
\hline $\mathrm{T} 5$ & 74.2 & 71.9 & 65.7 & 9.2 & 9.1 & 8.7 & 96.8 & 94.7 & 69.1 \\
\hline T6 & 73.2 & 68.2 & 66.9 & 9.2 & 8.9 & 8.8 & 91.6 & 86.9 & 77.0 \\
\hline $\mathrm{T} 7$ & 73.4 & 72.8 & 64.6 & 9.1 & 9.1 & 8.6 & 92.5 & 96.1 & 76.5 \\
\hline \multirow[t]{2}{*}{ Coefficient of variation (\%) } & \multicolumn{3}{|c|}{4.67} & \multicolumn{3}{|c|}{2.12} & \multicolumn{3}{|c|}{8.69} \\
\hline & \multicolumn{9}{|c|}{ Probability value for the F-test } \\
\hline Treatment $^{(2)}$ & \multicolumn{3}{|c|}{0.8197} & \multicolumn{3}{|c|}{0.6572} & \multicolumn{3}{|c|}{0.627} \\
\hline Year & \multicolumn{3}{|c|}{$<0.0001$} & \multirow{2}{*}{\multicolumn{3}{|c|}{$\begin{array}{c}<0.0001 \\
0.0036\end{array}$}} & \multicolumn{3}{|c|}{$<0.0001$} \\
\hline Treatment vs. year ${ }^{(3)}$ & \multicolumn{3}{|c|}{0.0867} & & & & \multicolumn{3}{|c|}{0.0727} \\
\hline Contrast $^{(4)}$ & \multicolumn{9}{|c|}{ Probability value } \\
\hline $\mathrm{C} 1$ & 0.489 & 0.148 & 0.321 & 0.287 & 0.303 & 0.116 & 0.542 & 0.239 & 0.462 \\
\hline $\mathrm{C} 2$ & 0.642 & 0.180 & 0.287 & 0.947 & 0.274 & 0.004 & 0.804 & 0.074 & 0.396 \\
\hline $\mathrm{C} 3$ & 0.789 & 0.472 & 0.446 & 0.588 & 0.641 & 0.408 & 0.815 & 0.350 & 0.733 \\
\hline $\mathrm{C} 4$ & 0.394 & 0.101 & 0.742 & 0.431 & 0.129 & 0.626 & 0.245 & 0.186 & 0.169 \\
\hline C5 & 0.740 & 0.312 & 0.581 & 0.949 & 0.186 & 0.133 & 0.702 & 0.238 & 0.296 \\
\hline C6 & 0.791 & 0.037 & 0.022 & 0.960 & 0.042 & 0.006 & 0.844 & 0.168 & 0.006 \\
\hline
\end{tabular}

(1) T1, heading of half of the mixed shoot; T2, heading of one third of the mixed shoot; T3, flower thinning in the pink bud stage; T4, thinning at full bloom; T5, thinning of fruit with $5 \mathrm{~mm}$; T6, thinning of fruit with $20 \mathrm{~mm}$; and T7, no thinning or heading (control). ${ }^{(2)} \mathrm{F}$-test significant at $5 \%$ probability. ${ }^{(2)} \mathrm{F}$-test significant at $25 \%$ probability. ${ }^{(3)} \mathrm{C} 1$, control vs. heading and thinning (T7 vs. T1, T2, T3, T4, T5, and T6); C2, heading vs. thinning (T1 and T2 vs. T3, T4, $\mathrm{T} 5$, and T6); $\mathrm{C} 3$, heading of half of the mixed shoot vs. heading of one third of the mixed shoot (T1 vs. T2); C4, thinning of fruit with $20 \mathrm{~mm}$ vs. thinning of fruit with $5 \mathrm{~mm}$ and flower thinning (T6 vs. T3, T4, and T5); C5, thinning of fruit with $5 \mathrm{~mm}$ vs. flower thinning (T5 vs. T3 and T4); and C6, flower thinning at the pink bud stage vs. thinning at full bloom (T3 vs. T4); contrasts are significant at $5 \%$ probability. 
the flowering stage, showing a similar behavior to that under conventional thinning (20-mm fruit). This expands the optimum period to perform hand thinning, increasing fruit size, with no changes in physicochemical characteristics. However, shoot heading, with no additional hand thinning, was inefficient.

\section{Conclusions}

1. Non-thinned 'BRS Kampai' peach (Prunus persica) trees show greater production, but smaller fruits.

2. Thinning during flowering and at the beginning of fruit growth increases fruit size.

3 . Shoot heading reduces plant production, but does not significantly increase fruit size.

\section{Acknowledgments}

ToConselho NacionaldeDesenvolvimento Científico e Tecnológico (CNPq, process No. 455.300/2014-3), for finacial support and for scholarship granted; and to Coordenação de Aperfeiçoamento de Pessoal de Nível Superior (Capes), for scholarships granted.

\section{References}

BERGAMASCHI, H.; MELO, R.W. de; GUADAGNIN, M.R.; CARDOSO, L.S.; SILVA, M.I.G. da; COMIRAN, F.; DALSIN, F.; TESSARI, M.L.; BRAUNER, P.C. Boletins Agrometeorológicos da Estação Experimental Agronômica da UFRGS: série histórica 1970-2012. Porto Alegre: Ed. da UFRGS, 2013. 8p. Available at: <http://www.ufrgs.br/agronomia/ joomla/files/EEA/Srie_Meteorolgica_da_EEA-UFRGS.pdf $>$. Accessed on: Dec. 32015.

BYERS, R.E.; COSTA, G.; VIZZOTTO, G. Flower and fruit thinning of peach and other Prunus. In: JANICK, J. (Ed.). Horticultural reviews. New York: J. Wiley \& Sons, 2003. v.28, p.352-392.

CITTADINI, E.D.; BALUL, Y.J.; ROMANO, G.S.; PUGH, A.B. Efecto de la intensidad y época de realización del raleo sobre el rendimiento y la calidad de fruto en el cultivo de cerezos. Revista de Investigaciones Agropecuarias, v.39, p.51-59, 2013.

DESNOUES, E.; GIBON, Y.; BALDAZZI, V.; SIGNORET, V.; GÉNARD, M.; QUILOT-TURION, B. Profiling sugar metabolism during fruit development in a peach progeny with different fructose-to-glucose ratios. BMC Plant Biology, v.14, p.336, 2014. DOI: 10.1186/s12870-014-0336-X.

EL-BORAY, M.S.; SHALAN, A.M.; KHOURI, Z.M. Effect of different thinning techniques on fruit set, leaf area, yield and fruit quality parameters of Prunus persica L. Batsch cv. Floridaprince.
Trends in Horticultural Research, v.3, p.1-13, 2013. DOI: 10.3923/thr.2013.1.13.

ETIENNE, A.; GÉNARD, M.; LOBIT, P.; MBEGUIÉ-AMBÉGUIÉ, D.; BUGAUD, C. What controls fleshy fruit acidity? A review of malate and citrate accumulation in fruit cells. Journal of Experimental Botany, v.64, p.1451-1469, 2013. DOI: 10.1093/ jxb/ert035.

FACHINELLO, J.C.; TIBOLA, C.S.; PICOLOTTO, L.; ROSSI, A. de; RUFATO, L. Produtividade e qualidade de pêssegos obtidos nos sistemas de produção integrada e convencional. Revista Brasileira de Fruticultura, v.27, p.64-67, 2005. DOI: 10.1590/ S0100-29452005000100018.

FERRER, A.; REMÓN, S.; NEGUERUELA, A.I.; ORIA, R. Changes during the ripening of the very late season Spanish peach cultivar Calanda: feasibility of using CIELAB coordinates as maturity indices. Scientia Horticulturae, v.105, p.435-446, 2005. DOI: 10.1016/j.scienta.2005.02.002.

GONÇALVES, M.A.; PICOLOTTO, L.; AZEVEDO, F.Q.; COCCO, C.; ANTUNES, L.E.C. Qualidade de fruto e produtividade de pessegueiro submetido a diferentes épocas de poda. Ciência Rural, v.44, p.1334-1340, 2014. DOI: 10.1590/0103$8478 \mathrm{cr} 20120617$.

GUGLIUZZA, G.; CARUSO, T.; INGLESE, P. Fruit and shoot growth, in relation to leaf vs. fruit ratio and their relative position in canopies of 'Flordastar' peach trees. Acta Horticulturae, v.592, p.493-499, 2002. DOI: 10.17660/ActaHortic.2002.592.66.

KONICA MINOLTA. Precise color communication: color control from perception to instrumentation. Japan, 2007.

LIMA, L.M. de; CAIXETA FILHO, J.V.; KASSOUF, A.L.; AMORIM, L. Valoração de atributos de qualidade em pêssegos comercializados no estado de São Paulo. Revista de Economia e Sociologia Rural, v.47, p.465-484, 2009. DOI: 10.1590/S010320032009000200007.

MYERS, S.C.; SAVELLE, A.T.; TUSTIN, D.S.; BYERS, R.E. Partial flower thinning increases shoot growth, fruit size, and subsequent flower formation of peach. HortScience, v.37, p.647$650,2002$.

OSBORNE, J.L.; ROBINSON, T. Chemical peach thinning: understanding the relationship between crop load and crop value. New York Fruit Quarterly, v.16, p.19-23, 2008.

PERECIN, D.; CARGNELUTTI FILHO, A. Efeitos por comparações e por experimento em interações de experimentos fatoriais. Ciência e Agrotecnologia, v.32, p.68-72, 2008. DOI: 10.1590/s1413-70542008000100010.

PRODUÇÃO AGRÍCOLA MUNICIPAL: culturas temporárias e permanentes. Rio de Janeiro: IBGE, 2014. v.41, 100p. Available at: <http://biblioteca.ibge.gov.br/visualizacao/periodicos/66/ pam_2014_v41_br.pdf>. Accessed on: Out. 92015.

RASEIRA, M. do C.B.; NAKASU, B.H.; BARBOSA, W. Cultivares: descrição e recomendação. In: RASEIRA, M. do C.B.; PEREIRA, J.F.M.; CARVALHO, F.L.C. (Ed.). Pessegueiro. Brasília: Embrapa, 2014. p.73-141.

RASEIRA, M. do C.B.; NAKASU, B.H.; UENO, B.; SCARANARI, C. Pessegueiro: cultivar BRS Kampai. Revista 
Brasileira de Fruticultura, v.32, p.1275-1278, 2010. DOI: 10.1590/S0100-29452011005000009.

SCARPARE FILHO, J.A.; MINAMI, K.; KLUGE, R.A. Intensidade de raleio de frutos em pessegueiros 'Flordaprince' conduzidos em pomar com alta densidade de plantio. Pesquisa Agropecuária Brasileira, v.35, p.1109-1113, 2000. DOI: 10.1590/ S0100-204X2000000600006.

SILVA, D.F.P.; SILVA, J.O. da C. e; MATIAS, R.G.P.; RIBEIRO, M.R.; BRUCKNER, C.H. Curva de crescimento e padrão respiratório de frutos de genótipos de pessegueiro em região de clima subtropical. Revista Brasileira de Fruticultura, v.35, p.642-649, 2013. DOI: 10.1590/S0100-29452013000200037.

SILVA, E.N.; DUARTE, J.B.; REIS, A.J. dos S. Seleção da matriz de variância-covariância residual na análise de ensaios varietais com medidas repetidas em cana-de-açúcar. Ciência Rural, v.45, p.993-999, 2015. DOI: 10.1590/0103-8478cr20141531.
SISTEMA brasileiro de classificação de solos. Brasília: Embrapa Produção de Informação; Rio de Janeiro: Embrapa Solos, 1999. p.16.

SZOT, I. Flower and fruit thinning effects on the development and quality of 'Sampion' apple fruits. Journal of Fruit and Ornamental Plant Research, v.18, p.129-138, 2010.

TREVISAN, R.; PIANA, C.F. de B.; TREPTOW, R. de O.; GONÇALVES, E.D.; ANTUNES, L.E.C. Perfil e preferências do consumidor de pêssego (Prunus persica) em diferentes regiões produtoras no Rio Grande do Sul. Revista Brasileira de Fruticultura, v.32, p.90-100, 2010. DOI: 10.1590/S010029452010005000011.

TURK, B.A.; FAJT, N.; STOPAR, M. Tergitol as a possible thinning agent for peach cv. Redhaven. Horticultural Science, v.41, p.49-54, 2014.

$\overline{\text { Received on September 9, } 2016 \text { and accepted on April 4, } 2017}$ 